\title{
Traffic-Generated Changes in the Chemical Characteristics of Size-Segregated Urban Aerosols
}

\author{
Wioletta Rogula-Kozłowska
}

Received: 29 January 2014/ Accepted: 16 August 2014/Published online: 29 August 2014

(C) The Author(s) 2014. This article is published with open access at Springerlink.com

\begin{abstract}
The road traffic impact on the concentrations of 13 fractions of particulate matter (PM) and their components was assessed. PM was sampled at two points in Katowice (southern Poland), a background point beyond the effects of road traffic, and a near-highway traffic point. The samples were analyzed for organic and elemental carbon, 8 water-soluble ions, 24 elements, and 16 polycyclic aromatic hydrocarbons (PAHs). The traffic emissions (mainly particles from car exhaust) enriched the ultrafine, submicron, and fine PM particles with elemental carbon. The traffic-caused re-suspension of the road and soil dust affecting the concentrations and chemical composition of the coarse PM fraction. However, for each PM fraction, the carcinogenic equivalent ratios, assumed as a measure of the hazard from 16 PAHs in this paper, were similar at the two sampling points. The traffic emissions from the highway appeared to have a weaker influence on the concentrations and chemical composition of PM in a typical urban area of southern Poland than elsewhere in Europe.
\end{abstract}

Keywords Vehicular traffic - Particulate matter . Chemical composition - Ultrafine particles · PAHs

The growth of road traffic causes the growth of health hazards from atmospheric aerosols (Schwartz 1997; Han and Naeher 2006). However, attributing this effect only to the traffic-related elevation of particulate matter (PM) concentrations, although most obvious, is a simplificationin great part the threat is due to the specific influence of traffic emissions on the chemistry of PM (Han and Naeher

W. Rogula-Kozłowska ( $₫)$

Institute of Environmental Engineering, Polish Academy of

Sciences, 34 M. Skłodowska-Curie St., 41-819 Zabrze, Poland

e-mail: wioletta@ipis.zabrze.pl
2006; Daher et al. 2014). In general, the ambient concentrations of PM-bound carbonaceous matter (including polycyclic aromatic hydrocarbons, elemental and organic carbon) are higher at crossroads and highways than in areas beyond the traffic influence (e.g. Harrison et al. 2004; Hueglin et al. 2005; Slezakova et al. 2010). The concentrations of PM-bound sulfates, nitrates, ammonium, chlorates, soil matter, and some elements at traffic-affected sites apparently differ from those in rural, urban, or suburban areas where the traffic effects are weaker (Harrison et al. 2004; Hueglin et al. 2005; Daher et al. 2014).

The goal of the work was to determine the differences in the chemical composition between various fractions of PM and to evaluate the road traffic influence on these differences in a typical urban area in southern Poland. PM was sampled in Katowice, at two sites differing in the traffic contributions to the air pollution. The concentrations, chemical composition, and exactness of the mass reconstruction (chemical mass closure) of each of thirteen following PM fractions: $\mathrm{PM}_{0.03-0.06}, \mathrm{PM}_{0.06-0.108}, \mathrm{PM}_{0.108-0.17}$, $\mathrm{PM}_{0.17-0.26}, \quad \mathrm{PM}_{0.26-0.4}, \quad \mathrm{PM}_{0.4-0.65}, \quad \mathrm{PM}_{0.65-1}, \quad \mathrm{PM}_{1-1.6}$, $\mathrm{PM}_{1.6-2.5}, \mathrm{PM}_{2.5-4.4}, \mathrm{PM}_{4.4-6.8}, \mathrm{PM}_{6.8-10}, \mathrm{PM}_{10-40}$ (subscript ranges are the intervals of the particle aerodynamic diameters $D_{p}$ in $\mu \mathrm{m}$ ) at these two sites are discussed in the paper.

\section{Materials and Methods}

Particulate matter was sampled simultaneously at two points in Katowice, a city in southern Poland with approximately 2,000,000 population. One of the points, UB (Fig. 1), was an urban background sampling point (2008/ 50/EC Directive), and was located beyond the effects of industrial and traffic emissions (the nearest road was $150 \mathrm{~m}$ away, and traffic density was less than 2,500 cars per $24 \mathrm{~h}$ ). 

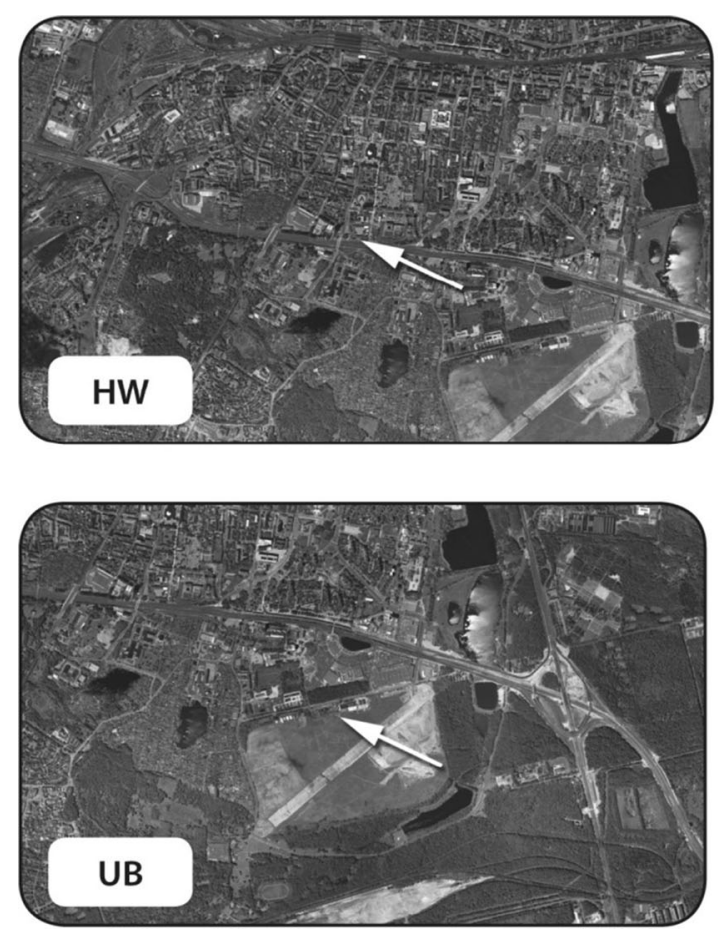

Fig. 1 Location of the measuring sites in Katowice

The area was a living district surrounded by greenbelts, about 2,000 $\mathrm{m}$ from the city center. The meteorological conditions at the point were typical of the region. The second point, HW (Fig. 1), was a traffic point located on the shoulder of the highway A4, about 1,500 m south of the city center and 1,200 $\mathrm{m}$ northwest of the point UB. Average traffic density at $\mathrm{HW}$ was 30,000 cars per $24 \mathrm{~h}$. To the north of HW, there was a living quarter. To the south, there was an open area of the A4 highway, and further behind $\mathrm{A} 4$, about $300 \mathrm{~m}$ from the point, there were some public utilities and detached houses of another living quarter. PM was sampled with the use of two thirteen-stage low pressure DLPI impactors (Dekati Ltd, Kangasala, FL).

In Katowice, especially in winter, traffic PM emissions can be obscured by emissions of PM from combustion of fossil fuels or biomass for residential heating (RogulaKozłowska et al. 2013; Rogula-Kozłowska and Klejnowski 2013). Therefore, the sampling period was selected beyond the major heating season, and the samples were taken within mid-March to mid-June of 2012. There were nine, about one-week long (from 142 to $173 \mathrm{~h}$ ), pairwise sampletakings.

The mass of the collected PM was determined by weighing the substrates before and after the exposure; a MYA 5.3Y.F micro balance (RADWAG; Radom, PL) was used $(1 \mu \mathrm{g}$ resolution). Before each weighing, the substrates were conditioned for $48 \mathrm{~h}$ in the weighing room (relative air humidity $45 \% \pm 5 \%$, air temperature $20 \pm 2^{\circ} \mathrm{C}$ ). The substrates and impactors were prepared for

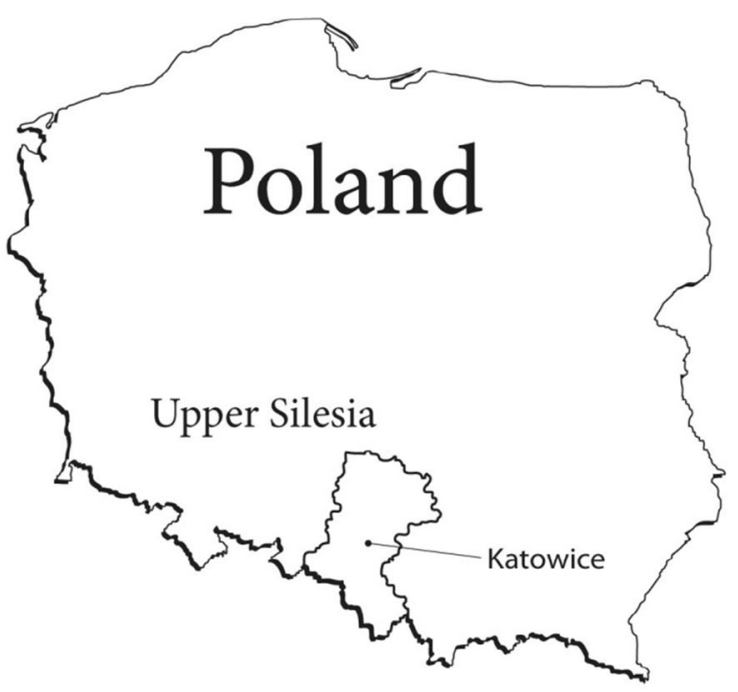

exposure in a laminar chamber. After weighing, the exposed substrates were stored in a freezer until analysis.

Two kinds of Whatman (GE Healthcare Bio-Sciences Corp.; Piscataway, NJ, USA) substrate filters were used. Alternating between the sample-takings, quartz fiber filters (QMA, ø25 mm, CAT No. 1851-025) and nylon membrane filters $(0.2 \mu \mathrm{m}, \emptyset 25 \mathrm{~mm}$, Cat No. 7402-002) were used; the former four and the latter five times. Always the same type substrates were used on all impactor stages, with the same type simultaneously used at both sampling points. Altogether, nine samples (four on quartz and five on nylon filters) of each of the 13 PM fractions were taken at each point over the entire measuring period.

At each point, four samples of each fraction were taken on quartz filters. Two equal $\left(1.5 \mathrm{~cm}^{2}\right)$ fragments were cut out from each quartz filter just before the analysis. The PM on one of them was analyzed for organic carbon (OC) and elemental carbon (EC). The remaining fragments, four for each of the 13 fractions and each point, were used to make fraction samples. A fraction sample for a point was made by putting together the four filter fragments containing this PM fraction sample from this point. Each of these 26 fraction samples was analyzed for 16 PAHs. ${ }^{1}$

\footnotetext{
1 The group of 16 PAHs included: naphthalene $(\mathrm{Na})$, acenaphthene (Ace), acenaphthylene (Acy), anthracene (An), benzo[a]anthracene $(\mathrm{BaA})$, benzo[a]pyrene (BaP), benzo[b]fluoranthene (BbF), benzo[k]fluoranthene $(\mathrm{BkF})$, benzo[g,h,i]perylene $(\mathrm{BghiP})$, chrysene $(\mathrm{Ch})$, dibenzo[a,h]anthracene (DBA), fluoranthene $(\mathrm{Fl})$, fluorene $(\mathrm{F})$, phenanthrene $(\mathrm{Ph})$, pyrene $(\mathrm{Py})$ and indeno[1,2,3-cd]pyrene (IP).
} 


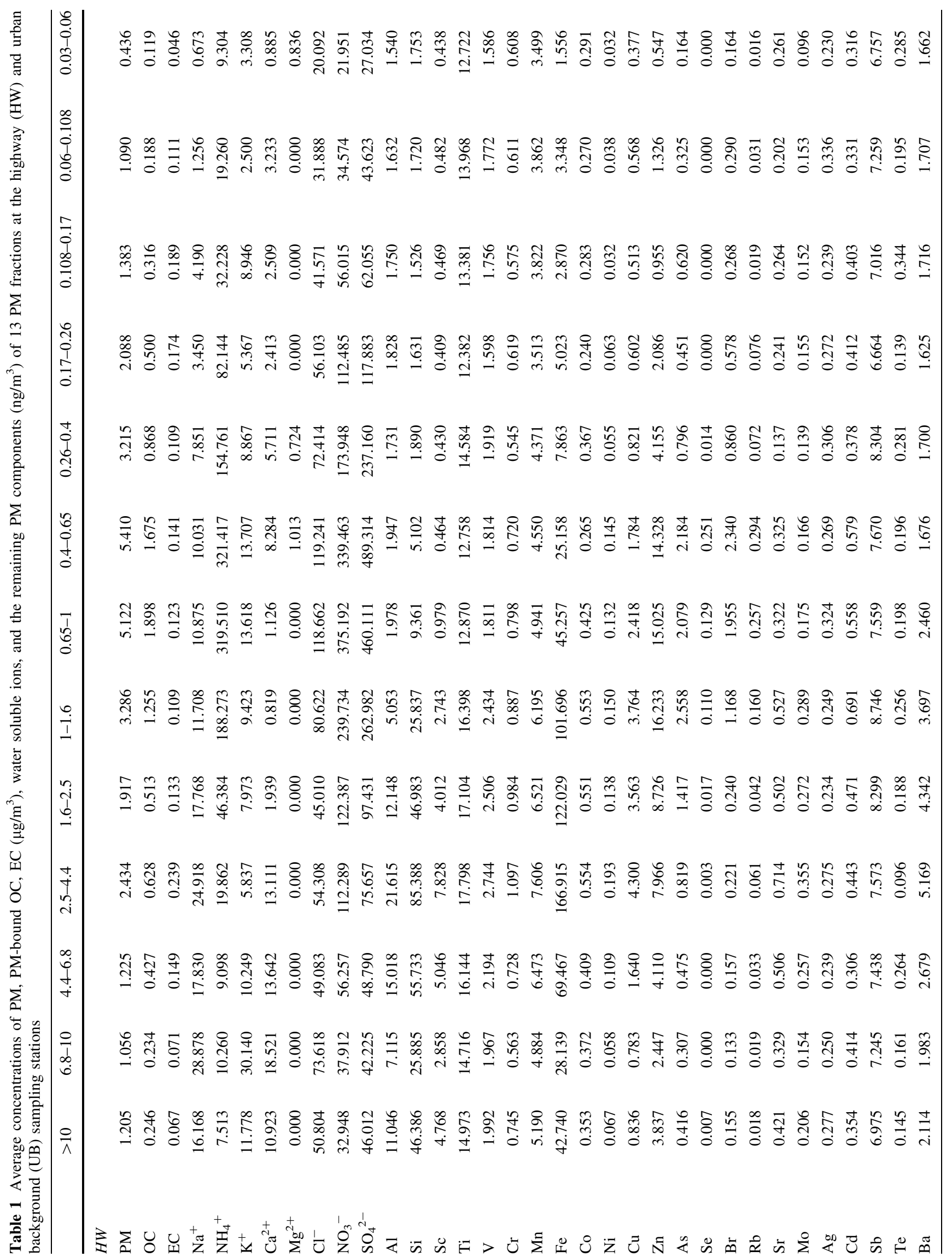




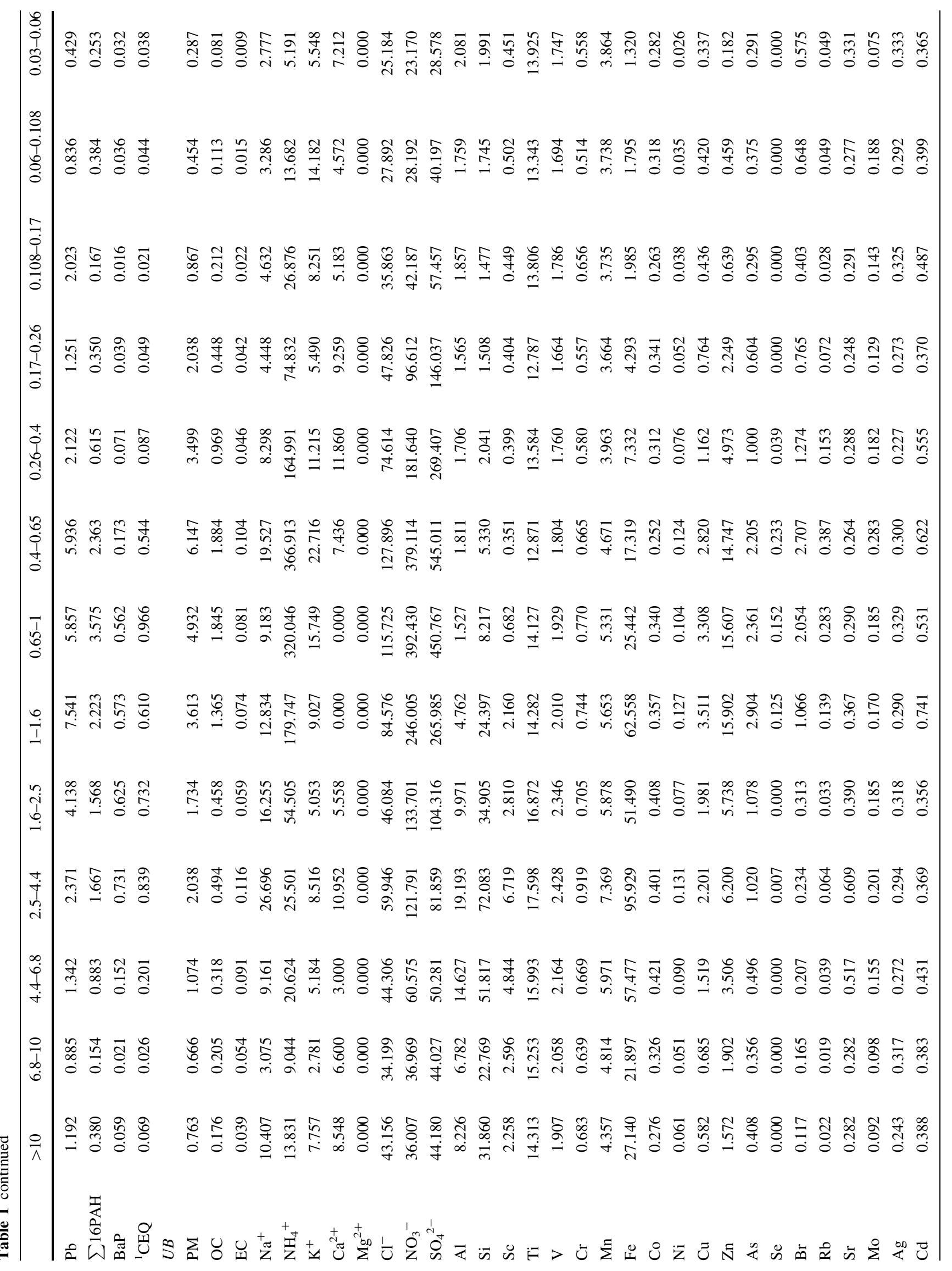




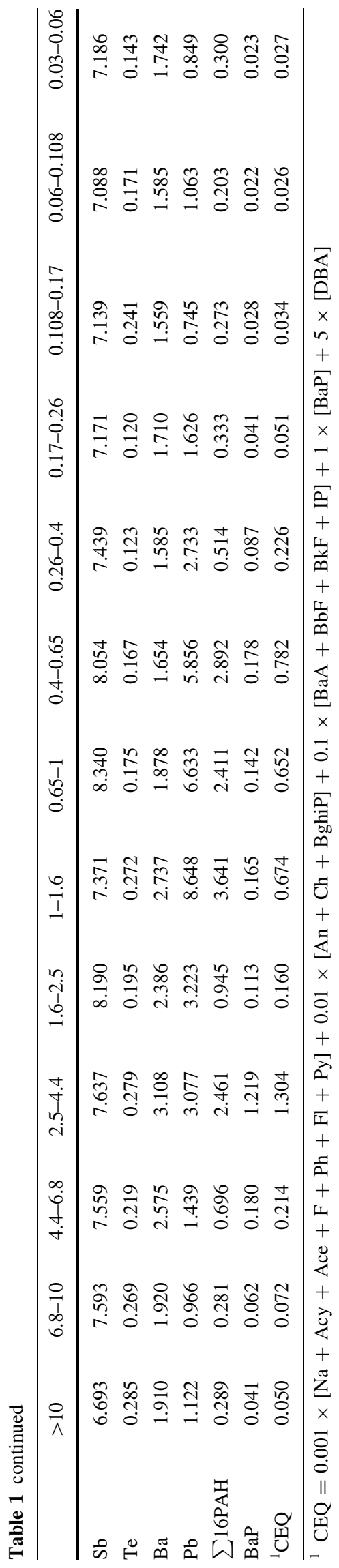

Five samples of each fraction were taken on nylon filters at each sampling point. The PM on each nylon filter was analyzed for elemental composition first (i.e. for $\mathrm{Al}, \mathrm{Si}, \mathrm{Sc}$, $\mathrm{Ti}, \mathrm{V}, \mathrm{Cr}, \mathrm{Mn}, \mathrm{Fe}, \mathrm{Co}, \mathrm{Ni}, \mathrm{Cu}, \mathrm{Zn}, \mathrm{As}, \mathrm{Se}, \mathrm{Br}, \mathrm{Rb}, \mathrm{Sr}, \mathrm{Mo}$, $\mathrm{Ag}, \mathrm{Cd}, \mathrm{Sb}, \mathrm{Te}, \mathrm{Ba}, \mathrm{Pb}$ ), then it was extracted in water and concentrations of the main ions $\left(\mathrm{Cl}^{-}, \mathrm{NO}_{3}{ }^{-}, \mathrm{SO}_{4}{ }^{2-}, \mathrm{Na}^{+}\right.$, $\mathrm{NH}_{4}{ }^{+}, \mathrm{K}^{+}, \mathrm{Ca}^{2+}, \mathrm{Mg}^{2+}$ ) were determined in the extracts.

The OC and EC contents of dust were determined with the use of a Lab OC-EC Aerosol Analyzer (Sunset Laboratories Inc.; Portland, OR, USA). Sixteen PAHs ${ }^{1}$ in the PM fractions were determined on a Clarus 500 gas chromatograph (PerkinElmer; Waltham, MA, USA). The analytical procedures, equipment, and quality control for OC, EC, and PAH in PM are described in Rogula-Kozłowska and Klejnowski (2013) and Rogula-Kozłowska et al. (2013).

The elemental composition of PM was determined by means of energy dispersive X-ray fluorescence (EDXRF). An Epsilon 5 instrument (PANalytical B.V.; Almelo, NL), calibrated with thin-layer single-element standards (Micromatter; Vancouver, BC,CA) was used to measure total concentrations of the elements. To control the performance of the analytical procedure, samples of reference material (SRM2873, NIST, Gaithersburg, MD, USA) were measured weekly. The recoveries were between $85 \%$ and $120 \%$ of the certified values (except $52 \%$ and $39 \%$ recoveries of $\mathrm{V}$ and $\mathrm{Co}$ ) and the $\mathrm{X}$-ray tube and detector drifts were monitored monthly. The detection limits were from $0.18 \mathrm{ng} / \mathrm{cm}^{2}$ (Se) to $19.6 \mathrm{ng} / \mathrm{cm}^{2}(\mathrm{Si}$ ).

The water extracts of PM were made by ultrasonizing the substrates containing the samples in $25 \mathrm{~cm}^{3}$ of deionized water for $60 \mathrm{~min}$ at $15^{\circ} \mathrm{C}$, then shaking for about $12 \mathrm{~h}\left(18^{\circ} \mathrm{C}, 60 \mathrm{r} / \mathrm{min}\right)$. The ion content of extracts was determined using an ion chromatograph (Metrohm AG; Herisau, $\mathrm{CH})$. The method was validated against the CRM Fluka products nos. 89316 and 89886; the standard recoveries were $92 \%-109 \%$ of the certified values, and the detection limits were: $10 \mathrm{ng} / \mathrm{cm}^{3}$ for $\mathrm{NH}_{4}{ }^{+}, 18 \mathrm{ng} / \mathrm{cm}^{3}$ for $\mathrm{Cl}^{-}, \mathrm{SO}_{4}{ }^{2-}$ and $\mathrm{K}^{+}, 27 \mathrm{ng} / \mathrm{cm}^{3}$ for $\mathrm{NO}_{3}{ }^{-}$and $\mathrm{Na}^{+}$, and $36 \mathrm{ng} / \mathrm{cm}^{3}$ for $\mathrm{Ca}^{2+}$ and $\mathrm{Mg}^{2+}$.

\section{Results and Discussion}

The average concentrations for the sampling period are presented in Table 1. In Katowice, the core PM mass consisted of particles with $\mathrm{D}_{\mathrm{p}}$ between 0.17 and $1.6 \mu \mathrm{m}$ $\left(\mathrm{PM}_{0.17-1.6}\right)$. They contributed $72 \%$ to the total PM mass at UB and $64 \%$ at HW (Table 1). The density function of the PM mass size distribution assumes the absolute maximum between 0.4 and $1.0 \mu \mathrm{m}$ at both sampling points (Fig. 2). It is clear that the concentrations of $\mathrm{PM}_{0.17-1.6}$ were not significantly affected by road traffic. 

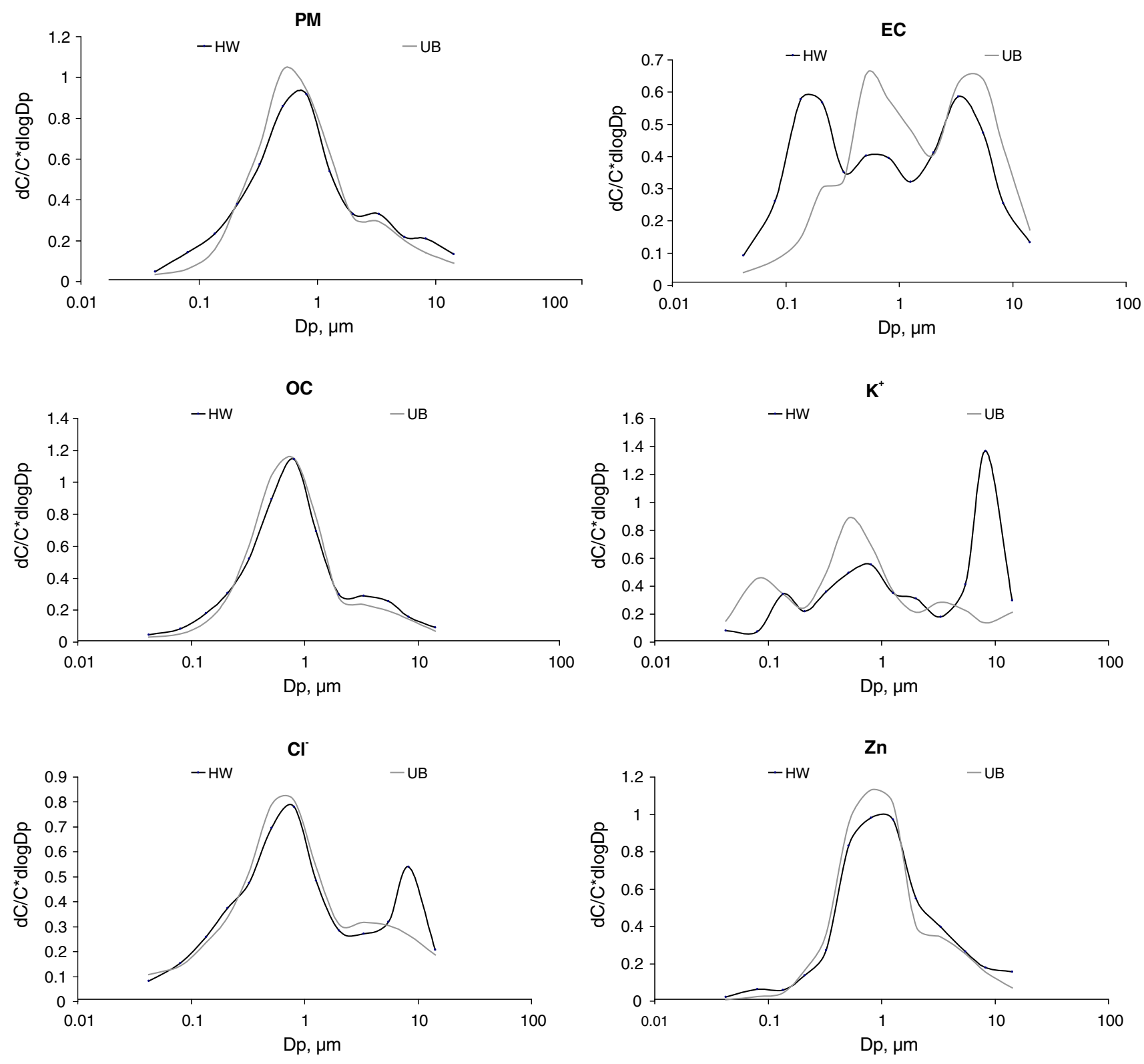

इ16PAH
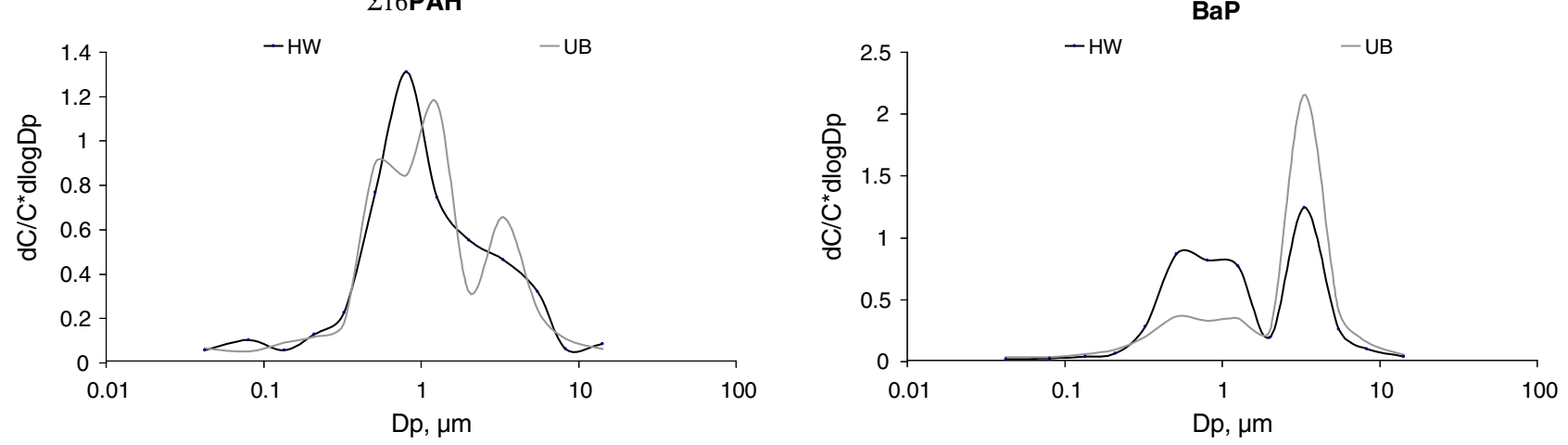

Fig. 2 Mass size distribution of PM and selected components of PM at urban background (UB) and at the highway (HW) 
The concentrations of $\mathrm{PM}_{0.17-1.6}$ and of its chemical components did not differ between the points except for (usually) traffic-related $\mathrm{Fe}, \mathrm{Co}, \mathrm{Ni}$, and $\mathrm{Mo}$ (Pant and Harrison 2013), and for EC.

In general, the fractionated EC concentrations were higher at HW than at UB. Within $\mathrm{PM}_{0.17-1.6}$, the concentrations of $\mathrm{PM}_{0.17-0.26^{-}}, \mathrm{PM}_{0.26-0.4^{-}}, \mathrm{PM}_{0.4-0.65^{-}}, \mathrm{PM}_{0.65-1^{-}}$, $\mathrm{PM}_{1-1.6}$-bound EC were from $40 \%$ to $>300 \%$ higher at HW than at UB. The concentrations of $\mathrm{PM}_{0.03-0.06}$,

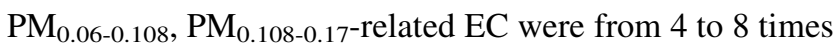
greater at $\mathrm{HW}$ than at UB. The striking difference in the behavior of the concentrations of PM-related EC between HW and UB can be seen by comparing the density functions of the mass distribution (relative to particle size) of EC bound to the nuclei and accumulation modes at HW and UB (Fig. 2).

Also, the concentrations of $\mathrm{PM}_{0.03-0.17}$ and of $\mathrm{PM}_{0.03-0.17}$-bound $\mathrm{OC}$ were higher at $\mathrm{HW}$ than at UB (averages of the concentrations of $\mathrm{PM}_{0.03-0.06}, \mathrm{PM}_{0.06-0.108}$, $\mathrm{PM}_{0.108-0.17}$, and of the related OC were higher by $84 \%$ and $54 \%$, respectively). The concentrations of $\mathrm{PM}_{0.03-0.17^{-}}$ related $\mathrm{Fe}, \mathrm{Cu}$, and $\mathrm{Zn}$ were also elevated at $\mathrm{HW}$. The density functions for some PM-related metals (e.g. Zn, Fig. 2) had maxima in the interval $0.03-0.17 \mu \mathrm{m}$ at $\mathrm{HW}$; these maxima did not exist at UB. Great differences in the

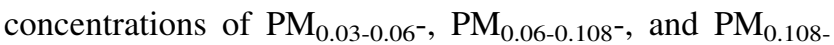
0.17-bound $\mathrm{EC}, \mathrm{OC}, \mathrm{Fe}, \mathrm{Cu}$, and $\mathrm{Zn}$ between the points are due to the chemical composition of car exhaust: car exhaust consists mainly of ultrafine particles of EC, OC (incomplete fuel combustion), substances synthesized from residues of fuel combustion, and lubricant or fuel additives (metals and their compounds, e.g.) (Geller et al. 2006; Maricq 2007).

Surprisingly, despite the significant PAH content of exhaust OC, the ambient concentrations of fine particlebound $\sum \mathrm{PAH}$ did not differ significantly between the points except for the $\mathrm{PM}_{0.06-0.108}$-bound $\sum \mathrm{PAH}$, higher at HW than at UB by $90 \%$. The density function of the PMbound $\sum \mathrm{PAH}$ distribution had the maximum in 0.06$0.108 \mu \mathrm{m}$. However, some from among the 16 PAHs had significantly higher concentrations at HW than at UB. The concentration of PM-bound $\mathrm{BaP}$ at $\mathrm{HW}$ was almost twice that for UB ( 4.3 and $2.3 \mathrm{ng} / \mathrm{m}^{3}$, respectively). The significantly higher $\mathrm{PM}_{0.03-1.6}$-bound $\mathrm{BaP}$ concentration at $\mathrm{HW}$ than at UB allows for consideration of $\mathrm{BaP}$ as a marker for exhaust emissions in urban areas of Upper Silesia in the periods of lower municipal emissions.

The concentrations of coarser PM $\left(\mathrm{D}_{\mathrm{p}}>4.4 \mu \mathrm{m}\right)$ and of some its components (OC, EC, $\mathrm{Na}^{+}, \mathrm{K}^{+}, \mathrm{Cl}^{-}, \mathrm{Ca}^{2+}, \mathrm{Al}, \mathrm{Si}$, $\mathrm{Fe}, \mathrm{Cu}, \mathrm{Zn}, \mathrm{Mo}$ ) also were higher at $\mathrm{HW}$. For example, the average concentrations of $\mathrm{PM}_{4.4-6.8^{-}}, \mathrm{PM}_{6.8-10^{-}}$, and $\mathrm{PM}_{10-}$ ${ }_{40}$-related $\mathrm{Na}^{+}$and $\mathrm{K}^{+}$were almost four times greater at $\mathrm{HW}$ than at $\mathrm{UB}$, while that for $\mathrm{Ca}^{2+}$ was approximately two-fold greater.
The PM mass size distribution was bimodal at UB. At HW, in $6.8-10 \mu \mathrm{m}$, the third peak for its density function appeared. Also the maxima of the density functions for $\mathrm{Na}^{+}, \mathrm{K}^{+}, \mathrm{Cl}^{-}$, and $\mathrm{Ca}^{2+}$ occurred in this interval. The coarse ambient particles containing $\mathrm{OC}, \mathrm{EC}, \mathrm{Na}^{+}, \mathrm{K}^{+}, \mathrm{Cl}^{-}, \mathrm{Ca}^{2+}, \mathrm{Al}, \mathrm{Si}, \mathrm{Fe}, \mathrm{Cu}$, $\mathrm{Zn}$, Mo are probably a mixture of the particles of worn tires, brake linings, chassis, other car parts, road surface, soil, etc. (Wahlin et al. 2006; Thorpe and Harrison 2008; Pant and Harrison 2013). Such particles, involved in the process of alternate lifting (by passing cars, wind, etc.) and deposition, can stay within the road vicinity for a long time.

The chemical mass closure of PM was checked at both points. There were six groups of identified chemical PM components, and the seventh one, unidentified matter (UM); their masses together made the total PM mass. The mass [EC] of elemental carbon (EC) was assumed to be the analytically determined mass $[\mathrm{EC}]_{\mathrm{A}}$ of elemental carbon: $[\mathrm{EC}]=[\mathrm{EC}]_{\mathrm{A}}$. The mass $[\mathrm{OM}]$ of organic matter $(\mathrm{OM}$, all PM-bound organic compounds) was assumed to be 1.4 of the analytically determined mass $[\mathrm{OC}]_{\mathrm{A}}$ of organic carbon $(\mathrm{OC}):[\mathrm{OM}]=1.4[\mathrm{OC}]_{\mathrm{A}}$. Secondary inorganic aerosol, SIA, consisted of $\mathrm{SO}_{4}{ }^{2-}, \mathrm{NO}_{3}{ }^{-}, \mathrm{NH}_{4}{ }^{+} ; \quad[\mathrm{SIA}]=\left[\mathrm{SO}_{4}{ }^{2-}\right]_{\mathrm{A}}$ $+\left[\mathrm{NO}_{3}{ }^{-}\right]_{\mathrm{A}}+\left[\mathrm{NH}_{4}{ }^{+}\right]_{\mathrm{A}} \cdot[\mathrm{NaCl}]=\left[\mathrm{Cl}^{-}\right]_{\mathrm{A}}+\left[\mathrm{Na}^{+}\right]_{\mathrm{A}}$.

The rest of the chemical components of PM listed in Table 1, i.e. the analytically determined PM-bound chemical elements (including $\mathrm{K}^{+}, \mathrm{Ca}^{2+}$, and $\mathrm{Mg}^{2+}$ ), were used to define crustal matter (CM) and trace elements (TE). The contents of CM and TE depended on both the PM fraction and the measuring point. These PM-bound elements were divided into two groups based on their enrichment factors EF (Rogula-Kozłowska et al. 2013; 2014). EF expresses how anthropogenic an element is: the closer an element's EF value is to 1, the smaller the anthropogenic contribution to the element's concentration in air.

The elements with $\mathrm{EF} \leq 20$ were assumed crustal (of natural origin). The chemical compounds containing an element with $\mathrm{EF} \leq 20$ that were known to contribute significantly to the PM mass were included in $\mathrm{CM}$; if there were no such compounds (known) for an element, or the element was probable to occur in numerous compounds, only the element was included in $\mathrm{CM}$. $\mathrm{CM}$ included $\mathrm{CO}_{3}{ }^{2-}, \mathrm{SiO}_{2}, \mathrm{Al}_{2} \mathrm{O}_{3}$, $\mathrm{Mg}^{2+}, \mathrm{Ca}^{2+}, \mathrm{K}_{2} \mathrm{O}$ (except $\mathrm{PM}_{0.4-0.65^{-}}$and $\mathrm{PM}_{0.06-0.108}$-bound $\mathrm{K}_{2} \mathrm{O}$ at $\mathrm{UB}$ ), $\mathrm{FeO}$ and $\mathrm{Fe}_{2} \mathrm{O}_{3}$ (except $\mathrm{PM}_{0.4-1.6}$-bound $\mathrm{FeO}$ and $\mathrm{Fe}_{2} \mathrm{O}_{3}$ at both points), $\mathrm{Rb}$ (except $\mathrm{PM}_{0.17-1.6}$-bound $\mathrm{Rb}$ at both points), $\mathrm{Sr}$ (except $\mathrm{PM}_{0.4-1.6^{-}}$and $\mathrm{PM}_{0.03-0.26}$-bound $\mathrm{Sr}$ at $\mathrm{HW}$, and $\mathrm{PM}_{0.03-1}$-bound $\mathrm{Sr}$ at UB), $\mathrm{PM}_{2.5-6.8}$-bound $\mathrm{Ba}$, and $\mathrm{Ba}$ from particles with $\mathrm{D}_{\mathrm{p}}$ greater than $10 \mu \mathrm{m}$. Except for $\mathrm{CO}_{3}{ }^{2-}$, the masses of the compounds (oxides) in $\mathrm{CM}\left(\mathrm{SiO}_{2}, \mathrm{Al}_{2} \mathrm{O}_{3}\right.$, $\mathrm{K}_{2} \mathrm{O}, \mathrm{FeO}$ and $\mathrm{Fe}_{2} \mathrm{O}_{3}$ ) were computed stoichiometrically from the masses of their component elements determined analytically; $\mathrm{Fe}$ was assumed to be distributed equally between $\mathrm{FeO}$ and $\mathrm{Fe}_{2} \mathrm{O}_{3}$. $\left[\mathrm{CO}_{3}{ }^{2-}\right]$ was computed from $\left[\mathrm{Ca}^{2+}\right]_{\mathrm{A}}$ and $\left[\mathrm{Mg}^{2+}\right]_{\mathrm{A}}$ (Marcazzan et al. 2001). 
The chemical elements with EF $>20$ were assumed to be anthropogenic; these many-source origin elements occurred in many PM-bound compounds that were not determined because of their multiplicity. These elements alone were put in TE. TE consisted of $\mathrm{K}^{+}$(only for $\mathrm{PM}_{0.4-}$ 0.65 and $\mathrm{PM}_{0.06-0.108}$ at UB), Sc, Ti, V, Cr, Mn, Fe (Fe at both points for $\mathrm{PM}_{0.4-1.6}$ only), $\mathrm{Co}, \mathrm{Ni}, \mathrm{Cu}, \mathrm{Zn}, \mathrm{As}, \mathrm{Se}, \mathrm{Br}$, $\mathrm{Rb}\left(\mathrm{Rb}\right.$ at both points for $\mathrm{PM}_{0.17-1.6}$ only), $\mathrm{Sr}$ (only for $\mathrm{PM}_{0.4-1.6}$ and for $\mathrm{PM}_{0.03-0.26}$ at $\mathrm{HW}$ and for $\mathrm{PM}_{0.03-1}$ at UB), Mo, Ag, Cd, Sb, Te, Ba (Ba only for $\mathrm{PM}_{0.03-2.5}$ and $\mathrm{PM}_{6.8-10}$ at both points), and $\mathrm{Pb}$. The mass [TE] of TE was assumed to be the sum of all the analytically determined masses of the elements from TE.

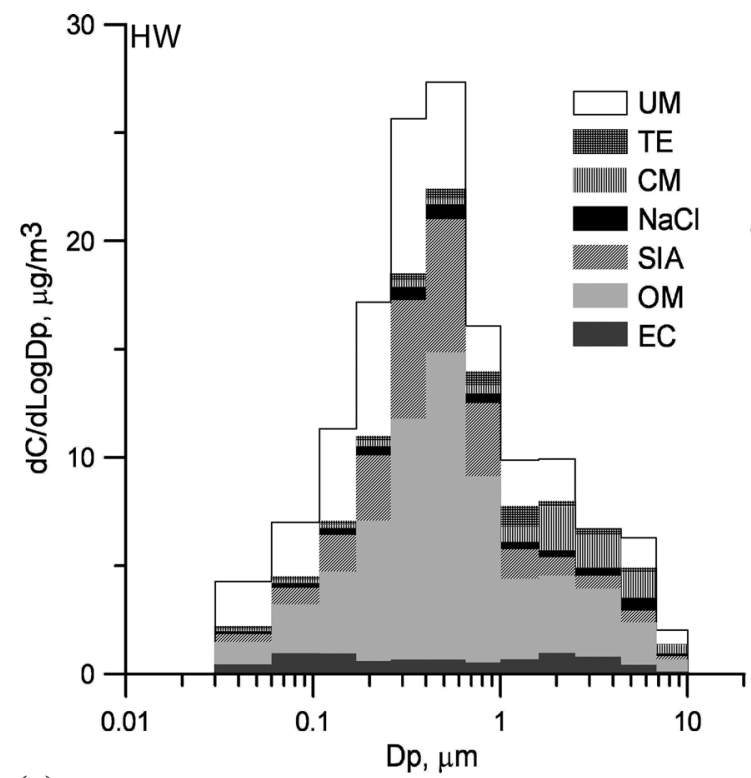

(a)
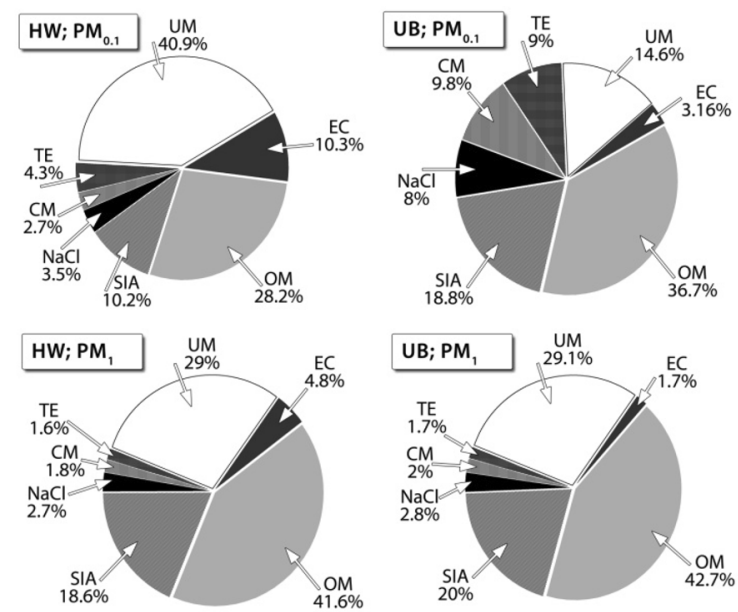

(b)

Fig. 3 Mass size distribution of the PM component groups (a) and the mass reconstruction of selected PM fractions (b) at traffic affected HW and at urban background UB (EC elemental carbon, $O M$ organic
The mass of unidentified matter [UM] was the deficient mass; it was the difference between the gravimetrically determined mass of PM and $[\mathrm{SIA}]+[\mathrm{EC}]+[\mathrm{OM}]+$ $[\mathrm{NaCl}]+[\mathrm{CM}]+[\mathrm{TE}]$.

In Fig. 3, the mass distributions of the PM component groups (relative to particle size) at both sites are presented. Within particular PM fractions, the identified matter accounted for the mass in $52 \%-98 \%$ at HW and in $55 \%$ $96 \%$ at UB. For all fractions except $\mathrm{PM}_{4.4-6.8}$, the mass of identified compounds was higher at UB than at HW.

The shares of UM in twelve PM fractions were greater, and in ultrafine PM much greater, at $\mathrm{HW}$ than at UB (Fig. 3). At $\mathrm{HW}$, the $\mathrm{UM}$ shares in $\mathrm{PM}_{0.06-0.65}$ and in
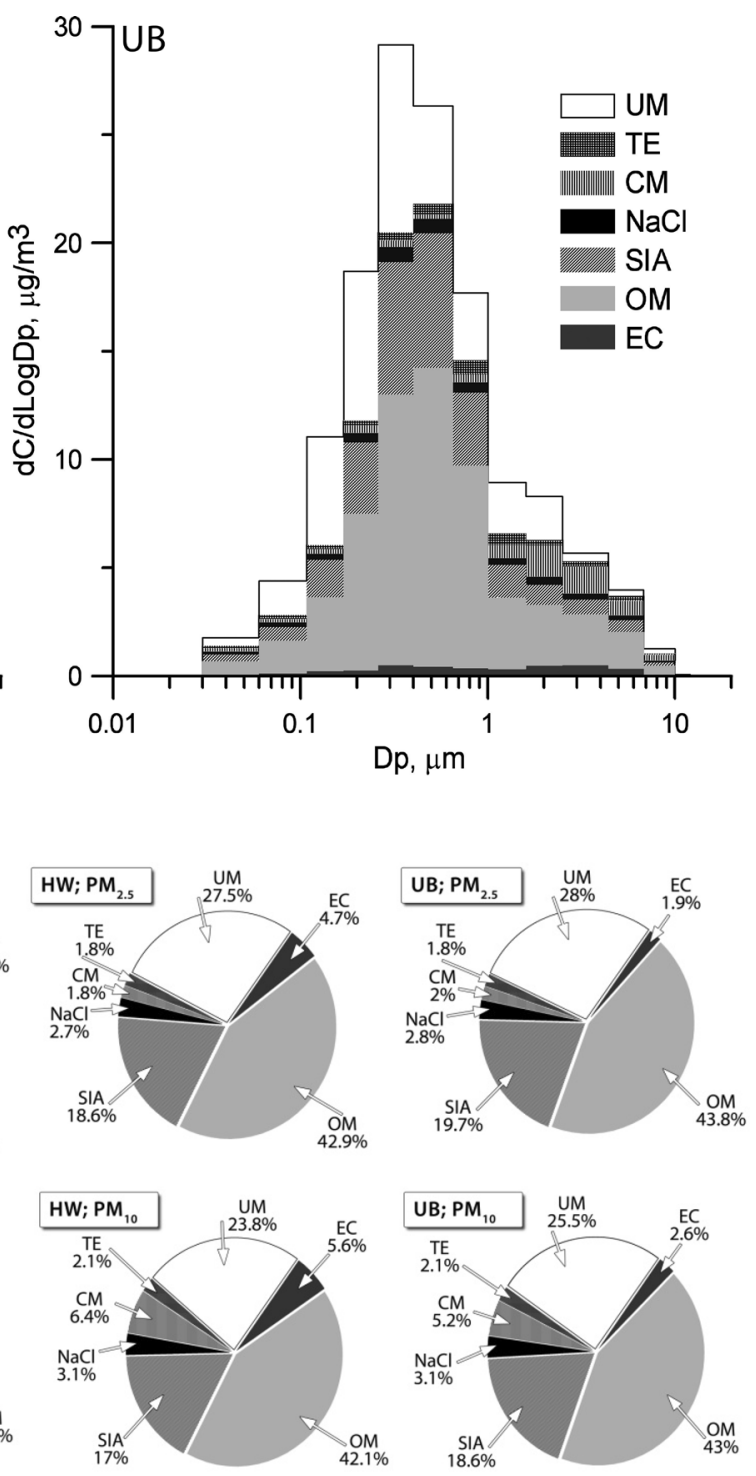

matter, SIA secondary inorganic aerosol, $\mathrm{NaCl}$ sum of $\mathrm{Na}^{+}$and $\mathrm{Cl}^{-}$, $C M$ crustal matter, $T E$ trace elements, $U M$ unidentified matter) 
particles with $D_{p}>10 \mu \mathrm{m}$ were greatest; whereas at UB, they were greatest in $\mathrm{PM}_{0.108-0.65}$ and $\mathrm{PM}_{1.6-4.4}$. UM consists of the organic compounds and nitrates that evaporate during transportation and storage of PM samples, unidentified compounds, and water (Tsyro 2005). Also, inaccurate identification of compounds in OM, CM and TE affects UM. For example at HW, considering the high UM content of 12 fractions, [OM] should probably have been computed by multiplying $[\mathrm{OC}]_{\mathrm{A}}$ by a coefficient greater than 1.4 (Turpin and Lim 2001).

The EC concentrations were higher at HW, and the EC mass distribution differed from that at UB (Table 1; Fig. 2). Therefore, the EC contributions to particular PM fractions, especially to finer ones, at $\mathrm{HW}$ were higher than at UB (Fig. 3). The fractional mass contributions of OM to $\mathrm{PM}$ at both points were close, and only for the sub-fractions of $\mathrm{PM}_{2.5-6.8}$ were they slightly higher (by $5 \%$ in average) at HW.

Although the concentrations of the components of SIA $\left(\mathrm{SO}_{4}{ }^{2-}, \mathrm{NO}_{3}{ }^{-}, \mathrm{NH}_{4}^{+}\right.$; Table 1$)$ at both points were comparable, the distributions of SIA and its mass contributions to the fractions differed slightly between the points. The contributions to $\mathrm{PM}_{0.03-0.108}$ and coarser particles $\left(D_{p}>4.4 \mu \mathrm{m}\right)$ were on average greater by 4 and $5 \%$ at $\mathrm{UB}$, respectively.

$\mathrm{NaCl}$ was more abundant at $\mathrm{HW}$ than at $\mathrm{UB}$ only in $\mathrm{PM}_{4.4-10}$. This was due to the previously mentioned differences in the ambient concentrations of $\mathrm{Na}^{+}$and $\mathrm{Cl}^{-}$ between the points. Similarly, the elevated concentrations of the components of $\mathrm{CM}$, especially of $\mathrm{K}^{+}, \mathrm{Ca}^{2+}, \mathrm{Al}$, Si, and $\mathrm{Fe}$, caused a slightly greater share of $\mathrm{CM}$ in $\mathrm{PM}_{1.6-10}$ at HW (CM contribution to the PM mass at UB was greater than at HW by no more than $2 \%$ ). The mass contribution of TE to $\mathrm{PM}_{0.65-1.6}$ was greater by about $2 \%$ at $\mathrm{HW}$ than at UB. The $\mathrm{NaCl}, \mathrm{CM}$, and TE contributions to fine, especially to ultrafine, PM were higher at UB than at HW because ultrafine PM had noticeably lower concentrations at $\mathrm{UB}$ (Fig. 3). $\mathrm{NaCl}$ and $\mathrm{TE}$ contain elements coming from energy production, traffic or industry at UB, and mainly from traffic (both exhaust and non-exhaust emissions) at HW (Pant and Harrison 2013; Kumar et al. 2013; RogulaKozłowska et al. 2014). Also CM in ultrafine PM, despite being "crustal," probably contains particles coming from exhaust gases and furnaces, including particles containing metal oxides from condensation (nuclei mode) (Geller et al. 2006; Maricq 2007).

The differences in the chemical composition of PM between the points were mainly in ultrafine and coarse PM. The distributions of the mass among the component groups differed extremely for $\mathrm{PM}_{0.1}$ (in fact $\mathrm{PM}_{0.03-0.108}$ ) between the two points (Fig. 3). $\mathrm{PM}_{1}$ and $\mathrm{PM}_{2.5}$ (in fact $\mathrm{PM}_{0.03-1}$ and $\mathrm{PM}_{0.03-2.5}$ ) differed between the points only in their $\mathrm{EC}$ content; $\mathrm{PM}_{10}$-in the EC and, greater by about $1 \%$ at
HW, CM contents (Fig. 3). The concentration of $\mathrm{PM}_{0.1}$ was two times greater at $\mathrm{HW}$ than at UB $\left(1.5\right.$ and $\left.0.7 \mu \mathrm{g} / \mathrm{m}^{3}\right)$, while the concentrations of $\mathrm{PM}_{2.5}$ and $\mathrm{PM}_{10}$ at $\mathrm{HW}$ were greater by no more than $5 \%$ (for $\mathrm{PM}_{10}$ they were $28.6 \mu \mathrm{g} / \mathrm{m}^{3}$ at $\mathrm{HW}$ and $27.3 \mu \mathrm{g} / \mathrm{m}^{3}$ at UB).

So, although the number of cars per person grows closer to the European average, traffic emissions are not as significant a PM source in the Silesian Agglomeration as they are in other European regions (e.g. Viana et al. 2008). In Katowice, $\mathrm{PM}_{0.17-1.6}$ contributes most to the $\mathrm{PM}$ mass, and traffic does not affect this PM fraction much. The concentrations and the chemical composition of this PM fraction within the Silesian Agglomeration are formed by municipal emissions, big power plants, and industry. The presented results show that human health is not more at risk near a big highway than some distance away. At both sampling points the carcinogenic equivalent ratios (CEQ) for particular PM fractions were close, both CEQ for total PM were equal to $4.2 \mu \mathrm{g} / \mathrm{m}^{3}$ (Table 1). As elsewhere in Poland, the concentration, chemical composition, and toxicity of PM in the Silesian Agglomeration depend on the season of the year; i.e., upon meteorological conditions and emissions from heat and power production facilities (Pastuszka et al. 2003, Majewski et al. 2011; RogulaKozłowska and Klejnowski 2013; Rogula-Kozłowska et al. 2014).

The present pioneering research shows that some differences in the chemical characteristics of $\mathrm{PM}_{4.4-10}$ between two sites in such a specific area as the Silesian Agglomeration can be found only by investigating particular fractions of $\mathrm{PM}_{4.4-10}$. However, the experiment should rather be considered as a pilot research and should be repeated on a wider scale at other traffic-affected sites, such as crossroads in a city center, street canyons, etc., to generalize the conclusions.

Acknowledgments The work was realized within the projects Nos. C.1.2. and N N523 564038, the former financed by the Institute of Environmental Engineering, PAS, the latter-by the Polish Ministry of Science and Higher Education.

Open Access This article is distributed under the terms of the Creative Commons Attribution License which permits any use, distribution, and reproduction in any medium, provided the original author(s) and the source are credited.

\section{References}

Daher N, Saliba N, Shihadeh AL, Jaafar M, Baalbaki R, Shafer MM, Schauer JJ, Sioutas C (2014) Oxidative potential and chemical speciation of size-resolved particulate matter (PM) at nearfreeway and urban background sites in the greater Beirut area. Sci Total Environ 470-471:417-426

Geller MD, Ntziachristos L, Mamakos A, Samaras Z, Schmitz DA, Froines JR, Sioutas C (2006) Physicochemical and redox 
characteristics of particulate matter (PM) emitted from gasoline and diesel passenger cars. Atmos Environ 40:6988-7004

Han X, Naeher LP (2006) A review of traffic-related air pollution exposure assessment studies in the developing world. Environ Int 32:106-120

Harrison RM, Jones AM, Lawrence RG (2004) Major component composition of PM10 and PM2.5 from roadside and urban background sites. Atmos Environ 38:4531-4538

Hueglin C, Gehrig R, Baltensperger U, Gysel M, Monn C, Vonmont $\mathrm{H}$ (2005) Chemical characterization of PM2.5, PM10 and coarse particles at urban, near-city and rural sites in Switzerland. Atmos Environ 39:637-651

Kumar P, Pirjola L, Ketzel M, Harrison RM (2013) Nanoparticle emissions from 11 non-vehicle exhaust sources-a review. Atmos Environ 67:252-277

Majewski G, Kleniewska M, Brandyk A (2011) Seasonal variation of particulate matter mass concentration and content of metals. Pol J Environ Stud 20:417-427

Marcazzan GM, Vaccaro S, Valli G, Vecchi R (2001) Characterisation of PM10 and PM2.5 particulate matter in the ambient air of Milan (Italy). Atoms Environ 35:4639-4650

Maricq MM (2007) Chemical characterization of particulate emission from diesel engines: a review. Aerosol Sci 38:1079-1118

Pant P, Harrison RM (2013) Estimation of the contribution of road traffic emissions to particulate matter concentrations from field measurements: a review. Atmos Environ 77:78-97

Pastuszka JS, Wawroś A, Talik E, Paw UKT (2003) Optical and chemical characteristics of the atmospheric aerosol in four towns in southern Poland. Sci Total Environ 309:237-251

Rogula-Kozłowska W, Klejnowski K (2013) Submicrometer aerosol in rural and urban backgrounds in southern Poland: primary and secondary components of $\mathrm{PM}_{1}$. Bull Environ Contam Toxicol 90:103-109
Rogula-Kozłowska W, Kozielska B, Klejnowski K, Szopa S (2013) Hazardous compounds in urban PM in the central part of Upper Silesia (Poland) in winter. Arch Environ Prot 39:53-65

Rogula-Kozłowska W, Klejnowski K, Rogula-Kopiec P, Ośródka L, Krajny E, Błaszczak B, Mathews B (2014) Spatial and seasonal variability of the mass concentration and chemical composition of $\mathrm{PM}_{2.5}$ in Poland. Air Qual Atmos Health 7:41-58

Schwartz J (1997) Health effects of air pollution from traffic: ozone and particulate matter. In: Fletcher T, McMichael AJ (eds) Health at the crossroads. Transport policy and urban health. Wiley, New York, pp 61-82

Slezakova K, Castro D, Pereira MC, Moralis S, Delerue-Matos C, Alvim-Ferraz MC (2010) Influence of traffic emissions on the carcinogenic polycyclic aromatic hydrocarbons in outdoor breathable particles. J Air Waste Manag Assoc 60:393-401

Thorpe A, Harrison RM (2008) Sources and properties of non-exhaust particulate matter from road traffic: a review. Sci Total Environ 400:270-282

Tsyro SG (2005) To what extent can aerosol water explain the discrepancy between model calculated and gravimetric PM10 and PM2.5. Atmos Chem Phys 5:515-532

Turpin BJ, Lim H-J (2001) Species contributions to PM2.5 mass concentrations: revisiting common assumptions for estimating organic mass. Aerosol Sci Tech 35:602-610

Viana M, Kuhlbusch TAJ, Querol X, Alastuey A, Harrison RM, Hopke PK, Winiwarter W, Vallius M, Szidat S, Prevot ASH, Hueglin C, Bloemen H, Wahlin P, Zecchi R, Kasper-Giebl A, Maenhaut W, Hitzenberger R (2008) Source apportionment of particulate matter in Europe: a review of methods and results. J Aerosol Sci 39:827-849

Wahlin P, Berkowicz R, Palmgren F (2006) Characterisation of traffic-generated particulate matter in Copenhagen. Atmos Environ 40:2151-2159 